Канукова 3. В. Персидское население Терской области во второй половине XIX - начале XX веков / 3. В. Канукова, 3. Т. Плиева, Б. В. Туаева // Научный диалог. - 2021. — № 11. C. 379-394. - DOI: 10.24224/2227-1295-2021-11-379-394.

Kanukova, Z. V., Plieva, Z. T., Tuaeva, B. V. (2021). Persian Population of Terek Region in Second Half of $19^{\text {th }}-$ early $20^{\text {th }}$ centuries. Nauchnyi dialog, 11: 379-394. DOI: $10.24224 / 2227-$ 1295-2021-11-379-394. (In Russ.).

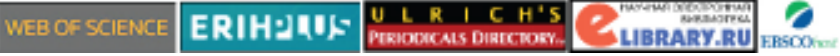

Журнал включен в Перечень ВАК

Персидское население Терской области во второй половине ХIX - начале XX веков

\section{Канукова Залина Владимировна ${ }^{1}$} orcid.org/0000-0002-7353-4324 доктор исторических наук, профессор z.kanukova@mail.ru

Плиева Залина Тимуровна ${ }^{2}$ orcid.org/0000-0002-9024-7175 кандидат исторических наук, доцент za-li@yandex.ru

Туаева Берта Владимировна ${ }^{2}$ orcid.org/0000-0001-9745-7776 доктор исторических наук, профессор ms.amaga@mail.ru

${ }^{1}$ Северо-Осетинский институт гуманитарных и социальных исследований им. В. И. Абаева - филиал Федерального государственного бюджетного учреждения науки Федерального научного центра «Владикавказский научный центр

Российской академии наук»

(Владикавказ, Россия)

${ }^{2}$ Северо-Осетинский

государственный университет имени Коста Левановича Хетагурова (Владикавказ, Россия)

\section{Благодарности:}

Исследование проведено при финансовой поддержке РФФИ, проект № 20-59-56005

\section{Persian Population of Terek Region in Second Half of $19^{\text {th }}$ Early 20 ${ }^{\text {th }}$ Centuries}

Zalina V. Kanukova ${ }^{1}$

orcid.org/0000-0002-7353-4324

Doctor of History, Professor z.kanukova@mail.ru Zalina T. Plieva ${ }^{2}$

orcid.org/0000-0002-9024-7175

$\mathrm{PhD}$ in History, Associate Professor za-li@yandex.ru

Berta V. Tuaeva ${ }^{2}$ orcid.org/0000-0001-9745-7776

Doctor of History, Professor ms.amaga@mail.ru

${ }^{1}$ V. I. Abaev North Ossetian Institute for Humanitarian and Social Studies - the Filial of the Vladikavkaz Science Centre of the Russian Academy of Sciences (Vladikavkaz, Russia)

${ }^{2}$ North Ossetian State University named after Kosta Levanovich Khetagurov (Vladikavkaz, Russia)

Acknowledgments:

The reported study was funded by RFBR, project number № 20-59-56005

(C) Канукова 3. В., Плиева 3. Т., Туаева Б. В., 2021 


\section{ОРИГИНАЛЬНЫЕ СТАТЬИ}

\section{Аннотация:}

Рассматривается миграционное движение населения Северного Ирана в Терскую область в эпоху ее пореформенной модернизации во второй половине XIX — начале $\mathrm{XX}$ веков. Рассмотрены причины, характер, время и особенности миграционной истории иранцев. Новизна исследования заключается в выявлении конкретных исходных пунктов миграции на территории Ирана, маршрутов продвижения по российской территории и мест поселения в Терской области. Особое внимание уделено исследованию социального состава и хозяйственной адаптации мигрантов. На основании архивных источников внесены коррективы в сложившиеся представления о социальных стратах, о трудовом характере миграции, об этническом составе переселенцев. Выявлены существенные отличия в положении мигрантов в Закавказье и на Северном Кавказе. Определена зависимость этих отличий от особенностей принимающего общества - Терской области в период пореформенной модернизации экономики и общественного развития. Определена специфика обустройства иранских мигрантов в отдельных национальных регионах области. Делается вывод, что этническое предпринимательство являлось основой адаптационного процесса и жизнеустройства мигрантов, внесших существенный вклад в развитие экономики региона.

\section{Ключевые слова:}

иранцы; отходничество; миграционная история; принимающее общество; этническое предпринимательство.

\section{ORIGINAL ARTICLES}

\section{Abstract:}

The migration movement of the population of Northern Iran to the Terek region in the era of its post-reform modernization in the second half of the 19th - early 20th centuries is considered. The reasons, nature, time and features of the migration history of the Iranians are considered. The novelty of the study lies in the identification of specific starting points of migration on the territory of Iran, routes of advancement on Russian territory and places of settlement in the Terek region. Particular attention is paid to the study of the social composition and economic adaptation of migrants. On the basis of archival sources, corrections were made to the prevailing ideas about social strata, about the labor nature of migration, and about the ethnic composition of migrants. Significant differences in the situation of migrants in the Transcaucasia and the North Caucasus are revealed. The dependence of these differences on the characteristics of the host society - the Terek region during the period of post-reform modernization of the economy and social development -is determined. The specifics of the arrangement of Iranian migrants in national regions of the region have been determined. It is concluded that ethnic entrepreneurship was the basis of the adaptation process and the life of migrants who made a significant contribution to the development of the region's economy.

Key words:

Iranians; migration history; host society; ethnic entrepreneurship. 


\section{Персидское население Терской области во второй половине XIX - начале XX веков}

Канукова 3. В., Плиева 3. Т., Туаева Б. В., 2021

\section{1. Введение}

Интерес к трансграничным миграциям как к своеобразным моделям этнических процессов и межэтнического взаимодействия в настоящее время существенно расширен пониманием миграций и формирующихся ими зарубежных диаспор как фактора глобального влияния на экономическое, политическое, этническое и культурное развитие современного мира. Это актуализирует обращение к богатому историческому опыту массовых миграционных движений и формирования зарубежных диаспор.

Терская область после проведения буржуазных реформ во второй половине XIX века в результате активного развития экономики и городского пространства стала привлекательным местом для представителей многих европейских и восточных этносов, которые формировали здесь свои диаспорные группы, что поощрялось миграционной политикой Российской империи.

Иранские диаспоры на Северном Кавказе формировались с 1860-х годов XIX века, главным образом, в городском пространстве региона, они внесли весомый вклад в его экономику, пережили вместе со всей Россией сложные процессы общественно-политических трансформаций первой трети XX века и стали непосредственным участником российско-северокавказского взаимодействия.

Миграционная история иранского населения на Северном Кавказе, в отличие от стран Закавказья и Средней Азии, не становилась предметом специального исследования, но без обращения к трудам историков, исследовавших проблему на обозначенных территориях, сложно понять причины и характер этой миграции.

Российские дореволюционные историки Л. К. Артамонов, Л. Ф. Тигранов, В. Ф. Минорский, Н. Бобынин, П. Я. Максимович-Васильковский [Артамонов, 1890; Бобынин, 1923; Максимович-Васильковский, 1904; Минорский, 1905; Тигранов, 1905] обстоятельно исследовали социально-экономическое положение Северо-Западного Ирана, причины отходнического движения иранцев в Закавказье, Астрахань и Среднюю Азию, уделив особое внимание тяжелым условиям труда иранских рабочих.

Иранские исследователи Мирза Мохаммед Назем-оль-Ислам Кермани, Мохаммад Амин Расулзаде [Кермани, 1910; Расул-Заде, 1998], советские историки, 
например Н. К. Белова [Белова,1956], охарактеризовали численность отходников на различных этапах многолетней миграции в Елизаветпольскую и Тифлисскую губернии, выявили сезонный и трудовой характер миграции, описали жесткую систему эксплуатации рабочих на нефтедобывающих предприятиях.

Современные исследователи расширили круг вопросов, связанных с миграцией иранцев. Так, К. Шукюров рассматривает отходничество иранского населения в контексте миграционной политики России. Обстоятельный анализ XIV и XV статей Туркманчайского договора 1828 года, Конвенции о передвижении подданных обоих государств 1944 года позволил автору выявить политико-правовые особенности миграционного движения [Шукюров, 2009, с. 210-216]. Иранисты Турадж Атабаки и Лана Раванди-Фадаи представили фундаментальный труд «Жертвы времени», в котором включили миграцию иранцев в Закавказье, Среднюю Азию, Астрахань и другие российские территории в широкий контекст иранской и российской истории, привлекли новые источники, позволившие выявить биографии персов, связавших свою судьбу с Россией [Атабаки и др., 2020].

В указанных работах не упоминались иранские мигранты на Северном Кавказе, долгое время этот аспект проблемы не становился предметом специального исследовательского внимания. Некоторое исключение прослеживается в историографии вопроса об иранских мигрантах Дагестана, которым посвящено несколько исследований [Дадаева, 2004; Дадаева и др., 2014], связанных с ролью иранцев в экономическом развитии региона.

Изучение истории иранцев в других районах Терской области активизировалось только в последние годы, после налаживания российскоиранских научных контактов. В частности, освещены демографические процессы в Терской области конца XIX — начала XX веков, в которых участвовали иранские мигранты [Хубулова и др., 2018]. Отдельные вопросы, связанные с иранцами в Осетии, рассмотрены в контексте изучения диаспорных групп; в частности, исследованы механизмы адаптации персов к городской среде Владикавказа [Канукова и др., 2019]; на основе российских и иранских архивных источников впервые исследована роль Владикавказского Генерального Персидского консульства в адаптационных процессах [Канукова и др. 2019]. Иранские историки А. Калирад и К. Каземи изучили условия пребывания граждан Ирана во Владикавказе на основании делопроизводственной документации Персидского консульства [Каземи,2019; Калирад, 2019]. Иранское население Дагестана привлекло внимание исследователей в контексте развития торгово-экономических отношений Ирана и России [Далгат, 2019; Мусаева, 2019].

В целом персидская община Северного Кавказа, в частности Терской области, так и не стала объектом исследования. Не выявлены раз- 
личия в положении мигрантов Терской области и Закавказья, остаются неизученными исходные пункты, маршруты и конечные точки миграции, нуждаются в корректировке сложившиеся представления о социальном и этническом составе переселенцев, об особенностях процесса адаптации мигрантов в национальных районах Терской области. Изучение этих и других вопросов необходимо для комплексного исследования обозначенной проблемы.

\section{2. Причины миграционного движения населения Северного Ирана на Северный Кавказ}

Иранские миграционные передвижения в Россию имеют давнюю историю. Персидское купечество с начала XVII века переправляло свои товары через Каспийское море в Астрахань, где со временем сформировалась многочисленная иранская диаспора. Миграции населения Ирана в сопредельные азербайджанские земли, в Грузию, Среднюю Азию активизировались в середине XIX века, что было обусловлено экономическим и социальнополитическим положением в стране.

Крупные землевладения принадлежали небольшому кругу иранской элиты, представленной феодалами, купцами, высшим духовенством и сановниками, которые захватывали общинные земли, практиковали издольную форму аренды земли на жестких условиях. Тяжелый физический труд, растущие поборы и налоги, невозможность возделывания земли из-за непригодности ирригационных сооружений, засухи и многолетние неурожаи разоряли основную массу крестьян.

Иностранные (английские и российские) инвестиции в промышленность, сельское хозяйство, строительство дорог, в банковское дело и торговлю давали Британии и России политические бонусы в виде контроля над правящей элитой и финансами страны. Новые возможности укрепляли позиции местной иранской знати, но главным социальным последствием активности иностранного капитала стало обнищание крестьян и ремесленников. Обилие дешевых иностранных фабричных товаров, появившихся на иранском рынке, подрывало традиционную ремесленную культуру и вовсе не способствовало развитию местной промышленности. Россия уделяла большое внимание североиранскому направлению внешней политики, поручив разработку стратегии экономического проникновения российского капитала в Иран министру экономики и финансов С. Ю. Витте.

Перспективы развития местного ремесла в мануфактурное, а затем в фабрично-заводское производство и основание акционерных компаний оказались несостоятельными из-за дефицита местного и политики иностранного капитала [Белова, 1956, с. 112]. Традиционное ковроткачество, 
как и другие промыслы и ремесла, по-прежнему были основаны на использовании самого дешевого женского и детского труда.

Обнищавшие земледельцы, ремесленники, наемные рабочие вынуждены были покидать родные места и пополнять ряды отходников, направлявшихся на заработки в Закавказье, Поволжье и Среднюю Азию.

В конце XIX века массовый отход на заработки населения Северо-Западного Ирана был связан прежде всего с «нефтяной лихорадкой» и развитием промышленности вокруг Баку. Для активно развивающейся российской экономики Иран стал источником дешевой рабочей силы.

\section{3. Исходные пункты, маршруты и размещение иранских мигрантов в Терской области}

Северо-Западный Иран, известный в исторической литературе как Иранский Азербайджан или Восточный Азербайджан Ирана, стал основной территорией исхода иранского населения в Россию. Между северными территориями Ирана и Закавказья существовали давние связи: иранские плотники и каменщики находили приют в Елисаветполе, Шуше, Эриване, Шемахе, Тифлисе [Белова, 1956, с. 113] и других районах Закавказья.

После двух русско-иранских войн и подписания Гюлистанского и Туркманчайского договоров Иран понес большие потери. По Гюлистанскому договору (1813) Иран потерял Северный Азербайджан. Туркманчайский договор (1828) означал переход в Россию Нахичеванского ханства и Ордубадского округа. Ирану же перешли азербайджанские территории южнее Аракса.

Исследователи отмечают, что капиталистические отношения на севере Ирана начали развиваться раньше, чем в остальном Иране, поэтому из других областей Ирана не было массового отходничества [Белова, 1956, c. 113]. Однако огромная территория страны и отсутствие транспортных путей сообщения вовсе не способствовали развитию отходничества из других районов Ирана.

Несмотря на размежевание границ между Ираном и Россией, практика свободного перемещения между северными территориями Ирана и Азербайджаном сохранялась долгое время. Этот процесс носил стихийный характер, игнорировались регламенты Туркманчайского договора, что обусловило необходимость принятия в 1844 году специальной Конвенции о правилах перемещения населения между Ираном и Россией, которая предусматривала обязательное наличие паспортов и разрешительных документов при пересечении границы государства. Но и эти меры не смогли упорядочить миграционные потоки. В течение всей второй половины XIX и начала XX веков этот вопрос оставался в повестке обеих стран, одной из причин тому была заинтересованность России в дешевых трудовых ресурсах. Поэтому были 
пролоббированы специальные распоряжения Кавказского наместничества, послабляющие требования Конвенции [Шукюров, 2009, с. 214].

К началу XX века приток иранских рабочих в Россию существенно увеличился. Исследования по вопросу миграции иранцев в Россию содержат множество разных цифр и за разные годы, но достоверность приведенной статистики вызывает большие сомнения, поскольку она не учитывает огромные потоки мигрантов, пересекающих границу нелегально. Это была широко распространенная практика в приграничных районах. Особенно отличался город Ардебиль и его окрестности, ставшие центром нелегальной миграции в Россию. По данным Л. Ф. Тигранова, из Ардебиля ежегодно уходило до 30 тысяч человек [Тигранов, 1905, с. 160-161]. Всего же, по подсчетам Н. К. Беловой, к 1905 году массовое отходничество достигало не менее 300 тысяч человек в год [Белова, 1956, с. 114].

Иранские историки Т. Атабаки и Л. Раванди-Фадаи, исследовавшие историю репрессированных в советские годы иранцев, сделали выборку из Книг памяти Республики Северная Осетия-Алания и Кабардино-Балкарской Республики. Привлечение к исследованию этого «случайного» для нас источника позволяет определить конкретные исходные пункты миграции иранцев, поселившихся на территории Северного Кавказа. В списках иранцев, ставших жертвами террора в советские годы, указывается место их рождения в Иране: города Тавриз, Шапур, Сараб, Ардебиль, Авшар, Гярмруд, Арванаг, Урмия, Хамна, Кармари, Тугархан; сельские поселения Сараи (провинция Керманшах), Сагандуз (Курдинский район Ирана), Дейран, Миане, Марандо, Мамаген, Мамагой, Амвей [Атабаки и др., 2020, с. 311-436].

Многими исследователями отмечался морской путь иранцев через портовые города Дагестана Петровск и Дербент, а также сухопутный через азербайджанские земли [Дадаева, 2004, с. 38].

Однако тезис о том, что эта территория стала пунктом дальнейшей миграции на Северный Кавказ [Хубулова и др., 2018], нуждается в корректировке. Основной маршрут для иранского населения, обосновавшегося во Владикавказе, Грозном, на кабардинских и балкарских землях, пролегал через Тифлис и Военно-грузинскую дорогу — древний исторический путь через Дарьяльское ущелье, соединявший Северный Кавказ и Закавказье. В начале XIX века была проведена реконструкция дороги, от Тифлиса до Владикавказа были обустроены станции: Тифлис, Мцхета, Цилкани, Душети, Ананур, Пасанаури, Млеты, Гудаури, Коби, Казбек, Ларс, Балта. Благоустроенная Военно-грузинская дорога стала связующим звеном между Россией и Закавказьем и способствовала развитию международных экономических отношений. Именно эта дорога с 1860 годов приводила на Северный Кавказ не только персов, но и азербайджанцев из Елизаветполь- 
ской губернии, армян, греков, грузин и представителей других ближневосточных народов.

Терская область попала в миграционную историю иранцев в результате миграционной политики России, своего географического положения и особенностей развивающейся экономики, которая предоставляла более выгодные и щадящие условия труда. Буржуазные реформы, активное включение во всероссийский рынок, развитие Владикавказа - административного, экономического и культурного центра области, других городов области, наличие железной дороги, потребность в людских ресурсах, благоприятный климат и дешевизна продуктов питания стали факторами притяжения мигрантов не только из Ирана, но и с других территорий. Это подтверждается и статистикой. В Терской области, по данным Первой Всероссийской переписи населения Российской империи, насчитывалось всего 3786 иностранцев, из них чуть больше половины составляли персидско-подданные [Первая ..., 1905, л. 14].

Персидско-подданные стали прибывать в Терскую область с 1860-х годов, их численность постоянно увеличивалась и к 1905 году составила 2431 чел. Анализ статистических данных, приведенных в Первой Всероссийской переписи населения Российской империи, показывает, что самым привлекательным для мигрантов оказался Владикавказский округ, где насчитывалось 1586 человек. В Грозненском округе зафиксировано 440 человек, в Кизлярском - 297, в Сунженском — 242, в Хасав-Юртовском 283, в Пятигорском — 784 человека [Там же, л. 25-28].

Мигрантов привлекали города, и прежде всего молодой город Владикавказ с пока еще свободными «нишами» в городском хозяйстве. В северокавказских традиционных обществах существовал строгий регламент землевладения и землепользования, поэтому персидские крестьяне могли заниматься привычным для себя земледельческим трудом только в небольшом числе и в качестве наемников.

\section{4. Этнический и половозрастной состав иранских мигрантов}

Практически все исследователи миграционного движения иранцев [Белова, 1956; Шукюров, 2009; Хубулова и др., 2018] считают, что мигрантами были этнические азербайджанцы или, как их именовали источники, турки.

Определение этнической принадлежности осложнено многими обстоятельствами. В российской историографии терминами перcbl, nepcbl-uuи$m b l$, uииты обозначали не только этнических персов и прибывших с ними турок, проживавших совместно на территории Тавриза и других районов Северного Ирана, но и азербайджанцев, жителей Закавказского края. 
В рамках другого определения - персидско-подданные - также невозможно определить их национальную принадлежность, поскольку это понятие включает подданных Ирана всех национальностей.

В Тавризе, Ардебиле и других районах Северного Ирана совместно проживали персы, азербайджанцы, армяне. Они совместно включались в миграционные потоки, при этом четко идентифицировали персов и турок, сохраняли этническую самобытность.

Об этом свидетельствует один архивный документ, в котором описан конфликт между персами и азербайджанцами по поводу шиитской мечети Владикавказа. Персидский мулла не знал «турецкого» языка, не вел метрических записей, не понимал этническую специфику религиозных обрядов. Азербайджанцы требовали отмежевания от персов в рамках отдельного прихода шиитской мечети, а со временем хотели строить свою мечеть. Описанная ситуация не оставляет сомнений в том, что среди мигрантов были этнические персы, которые сохраняли в условиях диаспоры свой язык и обряды, основали шиитскую мечеть при помощи Персидского консульства. В своих прошениях персы напоминали, что являются строителями и попечителями мечети, и при этом ссылались на свое большинство, указывая, что по своей численности они превосходили азербайджанцев в несколько раз [ЦГА РСО-А, ф. 11. оп. 17. д. 98. л. 2, 11]. Очевидно, что среди иранских мигрантов Владикавказа были этнические персы, к тому же превышавшие своей численностью азербайджанцев. Возможно, аналогичный этнический состав мигрантов был и в других городах Терской области.

Половозрастной состав иранских переселенцев свидетельствует о том, что миграция в Терской области отличалась от Закавказья преобладанием «постоянного населения» над «временно проживающим»; сезонных рабочих к началу ХХ века было немного. «Постоянное» население было представлено значительным числом женщин. Во Владикавказском округе значилось 1081 мужчина и 505 женщин, в Грозненском - 277 мужчин и 164 женщины, В Кизлярском - 204 мужчины и 93 женщины, в Нальчикском - 43 мужчины и 32 женщины, в Пятигорском - 504 мужчины и 280 женщин, в Сунженском 145 мужчин и 97 женщин, в Хасав-Юртовском - 177 мужчин и 106 женщин. В небольшом числе, но женщины были представлены и в категории сезонных мигрантов, которые составляли 111 человек, из них - 44 женщины [Первая ..., 1905, л. 14-28]. Анализ разрешительных документов подтверждает, что мигранты включали в свои прошения вопрос о проживании жен и детей.

\section{5. Социальная стратификация и хозяйственная адаптация мигрантов}

Советская и иранская историография не скупились на описание тяжелого положения «хамшахри» — иранских отходников в Закавказье. Мо- 
хаммад Амин Расул-заде писал, что иранские отходники работают больше всех, от 15 до 18 часов в день, за мизерную зарплату, плохо питаются, живут в малопригодных для этого помещениях в условиях антисанитарии [Rasulzadeh,1998, p. 78]. Действительно, огромное число отходников и их постоянный приток позволяли держать оплату и условия труда на предельно низком уровне.

В Терской области ситуация была не столь плачевна. При характеристике положения иранских мигрантов следует учитывать, что они делились на категории, что определяло разницу в их уровне жизни.

Сложнее всего приходилось «муздурам» - рабочим на фабриках и заводах, промышленных предприятиях, подвергавшимся нещадной эксплуатации, попадавшим в различные аварийные ситуации и получавшим в результате производственные травмы. Именно эта среда взрастила иранский пролетариат, ставший локомотивом революционных событий. В Терской области таких рабочих было немного. В основном они трудоустраивались на небольшие кирпичные заводы, были отмечены и в шахтах Садонского комбината в качестве «рабочих-крепильщиков» [Первая ..., 1905].

«Муздуры» были востребованы в Грозненском округе. В 1890-е годы там началась нефтяная «лихорадка», закладывались первые буровые скважины, вышки, прокладывались нефтепроводы, строились нефтеперегонные предприятия. Только на территории созданного Шейх-Мансуровского района к 1900 году было основано 4 завода по переработке нефти. Новые предприятия остро нуждались в рабочих. В качестве таковых нанимались местные жители: чеченцы, ингуши, казаки, русские переселенцы. Но это были неквалифицированные «чернорабочие», а владельцы нефтяных предприятий старались привлечь рабочих-иранцев, которые уже имели опыт, полученный в Закавказье. Съезд терских нефтепромышленников в 1916 году принял решение о «выписке» рабочих из Ирана, известных своей неприхотливостью и трудолюбием [Бакашов, 2017, с. 39-43]. Однако иранцы, приехавшие в Терскую область, не спешили на эти предприятия, потому что у них был выбор.

Немного легче приходилось отходникам - земледельцам, которые также получали мизерную плату за свой труд деньгами («фехле») или небольшой частью урожая («раншбер»), но были избавлены от опасных и тяжелых экологических условий работы на промышленных предприятиях. Эта категория отходников отмечена в кабардинских и балкарских селениях, в частности, в селении Кизляр Курпского района, Дейское и Терек Терского района, Каменномостское и Малка Нагорного района, Куба Кубинского района, Баксан, Псыхурей и Кызбурун Баксанского района, Кашхатау и Нижний Черек Черекского района. Из осетинских 
селений иранцы поселились только в мусульманском селении Чикола. Эти данные извлечены из списков иранцев, ставших жертвами репрессий [Атабаки и др., 2020, с. 21].

Еще одна категория персидских мигрантов - «амбалы». Так называли грузчиков и носильщиков, которые находили работу на железнодорожных станциях Терской области Муртазово, Прохладное, Кизляр, Эльхотовская, Колонка, Беслан, Владикавказ.

В городах иранские мигранты были представлены и другими социальными стратами: наряду с трудовыми мигрантами - ремесленниками и рабочими - во Владикавказе, Петровске, Дербенте и других городах обосновывались крупные торговцы, купцы, владельцы кирпичных заводов. Элита городского делового мира принимала на себя социальную ответственность за мигрантов-земляков, которые работали на их предприятиях, оказывала благотворительную помощь, в том числе и организованную в форме национальных благотворительных обществ.

В городах Терской области среди мигрантов были и представители иранской разорившейся знати, пытавшиеся восстановить свой статус и материальное благополучие на чужбине [ЦГА РСО-А. ф. 11, оп. 17. д. 98, л. 13]. Значились среди них и лица, которые на родине вошли в конфликт с шариатским законодательством, запрещавшим азартные игры и употребление спиртных напитков [НА СОИГСИ, ф. 4. оп. 1. д. 85, л. 3].

В городах Хасав-Юртовского округа иранцам удавалось создавать компактные поселения. В 1892 году в Темир-Хан-Шуре постоянно проживало 714 иранцев, в Петровске - 321, в Дербенте - 540 человек [Далгат, 2019, c. 55]. К концу ХІХ века практически во всех городах существовали персидские кварталы, в которых объединялись земляки - выходцы из одной провинции Персии. По предложению администрации Хасав-Юртовского округа, персидские колонии возглавляли старосты - представители торгово-промышленного делового мира мигрантов. Они осуществляли взаимодействие иранских мигрантов с властями округа, несли ответственность за нарушения законодательства [Дадаева и др., 2014, с. 14]. Иранские купцы владели кирпичными заводами, табачной фабрикой, чайными, пекарнями, создавали рабочие места для своих земляков. Иранцы занимались и сельским хозяйством, выращивали и продавали фрукты.

Во Владикавказе персы заняли свободные ниши городского хозяйства - торговлю, ремесленные промыслы, посредничество, бытовое обслуживание. В городе открывались персидские чайные, бакалейные магазины [ЦГА РСО-А. ф. 11. оп. 17. д. 98. л. 13], магазины по продаже ковров, персидские бани. Согласно материалам Первой всероссийской переписи населения, среди персов было много рабочих-строителей, которые могли 
производить кирпич и строить дома, сапожников, пекарей, мелких торговцев, цирюльников, банщиков, водовозов [Первая ..., 1905].

Прошения о принятии российского подданства, различные «разрешительные» и «водворительные» документы содержат информацию о хозяйственной деятельности ходатаев. По данным за период с 1908 по 1915 годы, около трети из них имели персидские магазины и кирпичные заводы во Владикавказе. Часть иранцев занимались разведением фруктовых садов, торговлей фруктами и национальными сладостями [ЦГА РСО-А, ф. 11, оп. 15 , д. 1209 , л. 2 ; ф. 11 , оп. 15 , д. 1419 , л. $1-2$; ф. 11 , оп. 15 , д. 141 , л. 2; ф. 11 , оп. 15 , д. 1424 , л. 2-3].

Еще одно отличие в положении мигрантов в Закавказье и на Северном Кавказе заключалось в характере трудовой миграции. Основную часть трудовых мигрантов в Баку и Тифлисе составляли сезонные рабочие, которые зимой возвращались в Иран (например, в 1906 году из 95132 тысяч иранцев 60524 вернулись на родину, в 1913 году из 274555 тыс. человек вернулось 213373 тыс. человек) [Атабаки и др., 2020, с. 21]. На Северном Кавказе отмечено преобладание осевших иранцев над сезонными. Первое время во Владикавказ на заработки также прибывали только мужчины [ЦГА РСО-А, ф. 11 , оп. 17 , д. 98, л. 11]. Однако со временем численность иранцев увеличилась за счет женского и детского населения. В конце XIX — начале XX веков персы стали приезжать во Владикавказ со своими семьями, о чем свидетельствуют сохранившиеся в архивах «водворительные свидетельства», выдаваемые для всех членов семьи [Там же, оп. 15, д. 887, л. 43] В 1882 году было зафиксировано 630 мигрантов, а по официальным данным за 1903 год число переселенцев достигло 2 тыс. человек [Канукова и др., 2019, с. 566].

Более того, несмотря на тяжелую жизнь, толкнувшую мигрантов к отходничеству, в Закавказье условия труда были настолько тяжелыми, что многие иранцы стали примыкать к рабочему движению, участвовать с 1880-1890-х годах в первых забастовках и стачках рабочих в Баку. Это могло не волновать работодателей, которые при поступлении на работу предлагали иранским отходникам приносить клятву на Коране в том, что они не станут бастовать.

Вместе с тем персы, проживавшие во Владикавказе, объясняли причины своей миграции прямой экономической выгодой: инфляция приводила к падению курса персидской монетной единицы - «крана». К примеру, в 1894 году три крана соответствовали одному руб., а в 1898 году — 5 руб. Такой денежный курс обусловил прибыльность работы: заработав сто рублей, персидский рабочий менял их по возвращении на родину на 500 кран. А этих денег хватало на покупку небольшого дома с земельным участком [Канукова и др., 2019, с. 565]. 
Более благоприятные условия жизни иранцев в Терской области в сравнении с Закавказьем определили и их политическую позицию. Они не только не примкнули к революционным событиям и не сочувствовали им, но и воспринимали происходящее как «сумасшедший дом», сетовали на понесенные убытки и вынужденную необходимость вернуться на родину [Калирад, 2018, с. 66-67].

\section{6. Заключение}

Причинами массовой миграции населения Северного Ирана в Россию стали экономический кризис, усугубленный давлением иностранного капитала, обнищание крестьян и ремесленников. Важным фактором, способствующим развитию отходничества, стала миграционная политика России, направленная на обеспечение дешевой рабочей силой развивающихся промышленных предприятий в регионе.

Основной территорией исхода иранского населения был Северный Иран, что связано с территориальной близостью к Закавказью, языковой и культурной общностью с его населением. Выявлены исходные пункты миграции: города Тавриз, Шапур, Сараб, Ардебиль, Авшар, Гярмруд, Арванаг, Урмия, Хамна, Кармари, Тугархан; сельские поселения Сараи (провинция Керманшах), Сагандуз (Курдинский район Ирана), Дейран, Миане, Марандо и ряд других. Установлено, что основной маршрут иранцев, прибывших во Владикавказский, Грозненский, Сунженский и Нальчикский округа Терской области, проходил не по дагестанской территории, а по Военно-грузинской дороге.

Терская область предоставляла мигрантам более благоприятные условия труда, чем закавказские губернии. Она попала в миграционный ареал в результате своего географического положения, развивающейся экономики и железнодорожного сообщения, потребности молодых городов в трудовых ресурсах, а также благодаря благоприятному климату и дешевизне продуктов питания.

Поэтому среди мигрантов численность постоянно проживающих значительно преобладала над числом сезонным рабочих, в половозрастном составе зафиксированы женщины и дети. Выявлено, что этнический состав мигрантов был представлен не только азербайджанцами (турками), но и персами.

Неоднородная социальная структура мигрантов включала крупных купцов, промышленников, разорившуюся знать, крестьян, ремесленников и рабочих. Последние имели широкий выбор хозяйственных занятий в городах.

Миграция иранского населения в Россию была взаимовыгодным процессом, она способствовала экономическому развитию Терской области. 


\section{ИСТОЧНИКИ И ПРИНЯТЫЕ СОКРАЩЕНИЯ}

1. НА СОИГСИ - Научный архив Северо-Осетинского института гуманитарных и социальных исследований им. В. И. Абаева. Ф. 4. «Этнография».

2. Первая Всеобщая перепись населения Российской империи 1897 г. Терская область. - Санкт-Петербург. 1905. — L. XVIII. - T. 68.

3. ЦГА РСО-Алания - Центральный государственный архив Республики Северная Осетия-Алания. Фонд 11. «Терское областное правление. Канцелярия общего присутствия».

\section{ЛИТЕРАТУРА}

1. Артамонов Л. К. Северный Азербайджан / Л. К. Артамонов. - Тифлис : Тип. Канцелярии главного начальника гражданской частью на Кавказе, 1890 . - 456 с.

2. Бакашов A. B. Экономическое развитие Чечни в пореформенный период (вторая половина XIX в.) / А. В. Бакашов // Историческая и социально-образовательная мысль. 2017. — Том 9. — № 1/2. — C. 3-43. — DOI: 10.17748/2075-9908-2017-9-1/2-39-43.

3. Белова Н. К. Об отходничестве из Северо-Западного Ирана в конце X1X - начале XX века / Н. К. Белова // Вопросы истории. - 1956. - № 10. - С. 112-121

4. Бобынин Н. Персия, ее экономическое положение и внешняя торговля в 19011923 гг. / Н. Бобынин. - Тифлис : Нар. ком. по внешней торговли ЗСФСР, 1923. — 557 с.

5. Дадаева Л. А. К вопросу об эмиграции персидских подданных в Дагестан (вторая половина XIX в.) / Л. А. Дадаева // Вестник ДГУ. Гуманитарные науки. — 2004. — Выпуск 3. - С. $38-42$.

6. Дадаева Л. А. Персидско-подданное население в Дагестане во второй половине XIX - начале XX веков : социально-экономический аспект / Л. А. Дадаева, А. И. Алиева // Известия Дагестанского государственного педагогического университета. Общественные и гуманитарные науки. - 2014. — № 4 (29). - С. 13-16.

7. Далгат Э. М. Иранцы в городах Дагестанской области во второй половине XIX - начале XX в. / Э. М. Далгат // Известия СОИГСИ. - 2019. - Выпуск 34 (73). C. 54 -62. - DOI: 10.23671/VNC.2019.73.42914.

8. Каземи К. Исследование роли Иранского консульства во Владикавказе в создании обстановки мирного сосуществования и развития ирано-российского сотрудничества : культурно-цивилизационные рамки / К. Каземи // Иран и Северный Кавказ : история и перспективы сотрудничества. Материалы Международной научно-практической конференции. - Владикавказ : Издательство СОГУ, 2018. — С. 68 - 69. — ISBN 978-5-8336-0957-6.

9. Калирад A. Поднятие красных флагов : гражданская война в России в докладах Консульства Ирана во Владикавказе / А. Калирад // Иран и Северный Кавказ : история и перспективы сотрудничества. Материалы Международной научно-практической конференции. - Владикавказ : Издательство СОГУ, 2018. — С. 66 - 67. — ISBN 978-5-8336-0957-6.

10. Канукова 3. В. Консульские службы в диаспорных процессах на Северном Кавказе (вторая половина XIX - первая треть XX века) / 3. В. Канукова, А. Калирад // Известия СОИГСИ. - 2019. - № 34 (73). — С. 45. — DOI: 10.23671/VNC.2019.73.42912.

11. Канукова 3. В. Персидская община во Владикавказе : механизмы сохранения этнической идентичности в инокультурной среде / 3. В. Канукова, Б. В. Туаева // Вестник российского университета дружбы народов. Серия : история России. - 2019. T. 18. — № 3. - C. 560 - 588. — DOI: 10.22363/2312-8674-2019-18-3-560-588.

12.Мирза МохаммадНаземаль-ИсламКермани.Историяиранскогопробуждения/Кер-

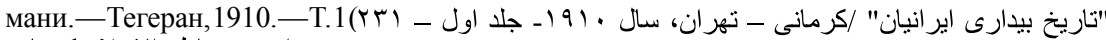

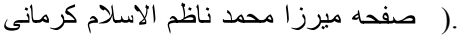


13. Максимович-Васильковский П. Я. Поездка в Персию / П. Я. Максимович-Васильковски // Известия Кавказского отдела императорского Русского географического общества. - 1904. - Т. XVII. — № 4. - С. 229-244.

14. Минорский В. Движение персидских рабочих на промыслы в Закавказье / В. Минорский // Сборник консульских донесений министерства внутренних дел. - 1905 . Выпуск 3. - С. 204-211.

15. Мохаммад Амин Расул Заде. “Отчеты об иранской конституционной революции”, переведенный Рахимом райснией / Мохаммад Амин Расул Заде. - Тегеран :

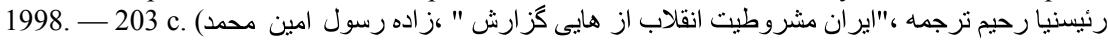

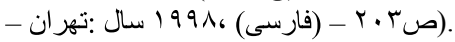

16. Мусаева С. И. Приморский Дагестан в истории культурно-экономического сотрудничества России и Ирана / С. И. Мусаева // Известия СОИГСИ. - 2019. - Выпуск 34 (73). — С. 73-83. — DOI: 10.23671/VNC.2019.73.43107.

17. Тигранов Л. Ф. Из общественно-экономических отношений в Персии / Л. Ф. Тигранов. — Тифлис : [б. и.], 1905. -247 с.

18. Турадж Атабаки. Жертвы времени. Жизнь и судьба иранских политических деятелей и трудовых мигрантов в межвоенный период / Т. Атабаки, Л. Раванди-Фадаи. Москва : ИВ РАН, 2020. — 532 с. — ISBN 978-5-89282-940-3.

19. Хубулова C. А. Персидско-подданное население Терской области в социальноэкономических и культурных процессах второй половины XIX - начале XX веков / С. А. Хубулова, Л. Ч. Хаблиева, 3. Е. Дзотцоева, С. С. Магомадов // Былые годы. 2018. - Выпуск 49 (3). - C. 1224-1236. — DOI: 10.13187/bg.2018.3.24.

20. Шукюров К. Миграция населения между Россией и Ираном в X1X - начале XX веков (политико-правовые вопросы) / К. Шукюров // Кавказ\&Глобализация. 2009. - Т. 3. - Выпуск 2-3. - С. 210-216.

\section{Material ResourCes}

Central State Archive of the Republic of North Ossetia-Alania. Fund 11. "Tersk Regional Board. The Office of the General Presence”. (In Russ.).

Scientific Archive of the North Ossetian Institute of Humanities and Social Studies named after V. I. Abaev. F. 4. "Ethnography”. (In Russ.).

The first General Population Census of the Russian Empire in 1897, the Tersk region, XVIII (68). (1905). St. Petersburg. (In Russ.).

\section{REFERENCES}

Artamonov, L. K. (1890). Northern Azerbaijan. Tiflis: Type of the Office of the chief Chief of the civil unit in the Caucasus. 456 p. (In Russ.).

Atabaki, T., Ravandi-Fadai, L. (2020). Victims of time. The life and fate of Iranian political figures and migrant workers in the interwar period. Moscow: IV RAS. $532 \mathrm{p}$. ISBN 978-5-89282-940-3. (In Russ.).

Bakashov, A. V. (2017). Economic development of Chechnya in the post-reform period (the second half of the XIX century). Historical and socio-educational thought, 9 (1/2): 3-43. DOI: 10.17748/2075-9908-2017-9-1/2-39-43. (In Russ.).

Belova, N. K. (1956). On the departure from Northwestern Iran at the end of the XIX - early XX century. Questions of history, 10: 112-121. (In Russ.).

Bobynin, N. (1923). Persia, its economic situation and foreign trade in 1901-1923. Tiflis: Nar. com. on Foreign trade of the ZSFSR. 557 p. (In Russ.). 
Dadaeva, L. A. (2004). On the issue of emigration of Persian subjects to Dagestan (the second half of the XIX century). Bulletin of the DSU. Humanities, 3: 38 - 42. (In Russ.).

Dadaeva, L. A., Aliyeva, A. I. (2014). The Persian-subject population in Dagestan in the second half of the XIX - early XX centuries: socio-economic aspect. News of Dagestan State Pedagogical University. Social sciences and humanities, 4 (29): 13-16. (In Russ.).

Dalgat, E. M. (2019). Iranians in the cities of Dagestan region in the second half of the XIX early XX century. Bulletin of the SOIGSI, 34 (73): 54 -62. DOI: 10.23671/ VNC.2019.73.42914. (In Russ.).

Kalirad, A. (2018). Raising red flags: the Civil war in Russia in the reports of the Iranian Consulate in Vladikavkaz. In: Iran and the North Caucasus: history and prospects of cooperation. Materials of the International Scientific and Practical Conference. Vladikavkaz: SOGU Publishing House. 66 - 67. ISBN 978-5-8336-0957-6. (In Russ.).

Kanukova, Z. V., Calidad, A. (2019). Consular service in Diaspora processes in the North Caucasus (second half of XIX - the first third of the twentieth century). Proceedings of SOIGSI, 34 (73): P. 45. DOI: 10.23671/VNC.2019.73.42912. (In Russ.).

Kanukova, Z. V., Tuaeva, B. V. (2019). The Persian community in Vladikavkaz: mechanisms of preserving ethnic identity in a foreign cultural environment. Bulletin of the People's Friendship University of Russia. Series: History of Russia, 18 (3): 560 - 588. DOI: 10.22363/2312-8674-2019-18-3-560-588. (In Russ.).

Kazemi, K. (2018). Research of the role of the Iranian Consulate in Vladikavkaz in creating an environment of peaceful coexistence and development of Iranian-Russian cooperation: cultural and civilizational framework. In: Iran and the North Caucasus: history and prospects of cooperation. Materials of the International Scientific and Practical Conference. Vladikavkaz: SOGU Publishing House. 68-69. ISBN 978-5-8336-0957-6. (In Russ.).

Khubulova, S. A., Khablieva, L. Ch., Dzottsoeva, Z. E., Magomadov, S. S. (2018). The Persian-subject population of the Tersk region in the socio-economic and cultural processes of the second half of the XIX - early XX centuries. Bygone Years, 49 (3): 1224 -1236. DOI:10.13187/bg.2018.3.24. (In Russ.).

Maksimovich-Vasilkovsky, P. Ya. (1904). Trip to Persia. Bulletin of the Kavkazskogo dept. of the Imperial Russian Geographical Society, XVII (4): 229-244. (In Russ.).

Minorsky, V. (1905). Movement of Persian workers to crafts in Transcaucasia. In: Collection of consular reports of the Ministry of Internal Affairs, 3: 204-211. (In Russ.).

Mirza Mohammad Nazem al-Islam Kermani. (1910). "The Story of the Iranian Awakening”, 1. Tehran. (In Pers.).

Mohammad Amin Rasul Zadeh. (1998). "Reports on the Iranian Constitutional Revolution”. Tehran. 203 p. (In Pers.).

Musayeva, S. I. (2019). Primorsky Dagestan in the history of cultural and economic cooperation between Russia and Iran. Bulletin of the SOIGSI, 34 (73): 73-83. DOI: 10.23671/VNC.2019.73.43107. (In Russ.).

Shukyurov, K. (2009). Migration of the population between Russia and Iran in the X1X - early XX centuries (political and legal issues). Caucasus\&Globalization, 3 (2-3): 210-216. (In Russ.).

Tigranov, L. F. (1905). From socio-economic relations in Persia. Tiflis: [b. i.]. 247 p. (In Russ.). 